\title{
Limits on Use of Diesel in Brazil: Measurement of Increase of Biodiesel in Mitigation of GHG
}

\author{
VALLÊNCIA MAÍRA GOMES \\ PhD Student in Socio-environmental Development (NAEA/UFPA), BRAZIL. E-mail: \\ vallmaira@gmail.com
}

\begin{abstract}
ALEXANDRE MAGNO DE MELO FARIA
Professor Assistant III in the Faculty of Economics at FEDERAL UNIVERSITY OF MATO GROSSO (UFMT), BRAZIL.E-mail:melofaria@cpd.ufmt.br
\end{abstract}

\begin{abstract}
Once set the mitigation of greenhouse gases in the National Policy on Climate Change (NPCC) with the National Program for Production and Use of Biodiesel (NPPB) in Brazil, this paper aims to estimate the need for biodiesel blended with petroleum diesel to 2020, taking into account the expansion limits of diesel. To estimate the future demand for diesel and $\mathrm{CO}_{2}$ emissions, the Box-Jenkins methodology and top-down were used respectively. The results show that the mixture in Brazil is expected to reach between B 31 ( $31 \%$ of blend) and B67 (67\% of blend) in 2020, to meet the objectives of the NPCC.
\end{abstract}

Keywords: Biofuel, Ecological Economics, Sustainable Scale.

\section{Límites en el uso de diésel en Brasil: La medición de aumento de biodiesel en la mitigación de GEI}

\begin{abstract}
RESUMEN
Una vez establecida la mitigación de los gases de efecto invernadero en la Política Nacional de Cambio Climático (PNCC) con el Programa Nacional de Producción y Uso de Biodiesel (PNPB) en Brasil, este trabajo pretende estimar la necesidad de biodiesel mezclado con gasoil hasta 2020, teniendo en cuenta los límites a la expansión del gasoil. Para estimar la futura demanda de gasoil y sus emisiones de $\mathrm{CO}_{2}$, se utilizó la metodología de Box-Jenkins y top-down respectivamente. Los resultados muestran que la mezcla en Brasil podría alcanzar entre el B31 (el 31\% de mezcla) y el B67 (el 67\% de mezcla) en 2020, para cumplir con los objetivos de la PNCC.
\end{abstract}

Palabras clave: Biocombustible, economía ecológica, escala sostenible.

Clasificación JEL: Q16, Q57, Q01

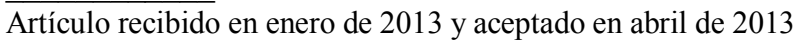

Artículo disponible en versión electrónica en la página www.revista-eea.net, ref. ə-31111 


\section{INTRODUCTION}

Resulting from global environmental issues and the post-Kyoto discussions, Brazil enacted, in December 2009, the Federal Law No. 12,187 that instituted the "National Policy on Climate Change" (NPCC). According to Article 12 of this law, Brazil "adopted as a national voluntary commitment, actions for the mitigation of greenhouse gases emission (GHG), aiming to reduce from $36.1 \%$ to $38.9 \%$ its projected emissions by $2020 "$. And it says that "the projection of emissions for 2020, as well as detailing of the actions to achieve the stated goal, will be disposed by decree, based on the second Brazilian Inventory of Anthropogenic Emissions and Removals of Greenhouse Gases not Controlled by the Montreal Protocol" (BRAZIL/CASA CIVIL, 2009).

The second edition of the inventory, published in October 2010, completes the article 12 of the NPCC, claiming that the national target to reduce the projected emissions between $36.1 \%$ and $38.9 \%$ by 2020 will be based on the values of the emissions of 2005 (BRAZIL/MCT, 2010). To achieve the primary goal of reducing GHG emissions were undertaken eleven mitigation actions listed in the second inventory. This paper, therefore, makes a cutout for the power sector, specifically sub-sector of transport, then, for actions that aim to reduce the impacts of GHG directly by the use of fossil fuels.

The Brazil's data reported in the second climate change statement shows that in 2005 were released 1.879 billion tons of GHG. Among these gases, the biggest pollutant is the carbon dioxide $\left(\mathrm{CO}_{2}\right)$ which represented $87.17 \%$ of GHG emissions, equivalent to 1.637 billion $\mathrm{tCO}_{2}$. The energy sector holds the second place when it comes to carbon emissions, representing $19 \%$ of it, equivalent to 313 million $\mathrm{tCO}_{2}$; holding on the first place is the sector of land-use change and forestry, which accounts for $77 \%$ of $\mathrm{CO}_{2}$ emissions. Within the energy sector, the transport sub-sector is the largest emitter, responsible for $44.5 \%$ of $\mathrm{CO}_{2}$ emissions of the sector (BRAZIL/MCT, 2010).

The main fuels used in the Brazilian transportation sector are diesel, gasoline and ethanol. And considering the mitigation actions, in this study, it highlights the action that addresses the mitigation by increasing the use of biofuels in a range of estimated reduction between 48 to 60 million tons equivalent of $\mathrm{CO}_{2}$ (BRAZIL/MCT, 2010). When the subject is renewable energy, ethanol has considerable participation in the Brazilian energy matrix. Therefore, the great Brazilian challenge concerning renewable fuel is to ensure biodiesel on the market, since the ethanol market is, in a way, consolidated to meet the light vehicles.

Then it is understood that to accomplish the NPCC's goal, in particular by the increase of biofuels use, the differential will be given by the greater use of biodiesel replacing petroleum diesel. In terms of the transportation sector, we understand that: first, the gasoline currently sold (type C) has a relevant per- 
centage of ethanol ethyl (ranging between $21 \%$ and $25 \%$ ), so the vehicles powered only by gasoline consume indirectly a share of renewable fuel; and second, the use of hydrous ethanol as a substitute to gasoline $\mathrm{C}$ for those vehicles framed in the category flex-fuel. Therefore, to meet the reduction established in NPCC as the action increment of biofuel, biodiesel is a solution and a challenge at the same time.

Biodiesel production has emerged in Brazilian agribusiness sector in the last seven years. With the implementation of the National Program for Production and Use of Biodiesel (NPPB) in 2005, the country initiated with an incipient production. The bet of the Brazilian government with the introduction of biodiesel mixed with diesel in the energy matrix mixed was to reduce dependence on imported diesel to be more precise. In addition to encouraging the use of renewable energy given its environmental contribution, when it comes to the mitigation of greenhouse gases of vehicle source. Besides the environmental point of view, this market created by governmental intervention, aims the social inclusion. Being biodiesel a derivative of oilseed biomass, such as castor, palm, sunflower, jatropha, soybean and cottonseed, the NPPB states that a percentage of the raw material, as determined by law, is purchased from family farms. The NPPB's proposal seeks to include up on the pillars of sustainability.

Currently, the biodiesel blend with diesel is $\mathrm{B}^{1}$ (or $5 \%$ of blended biodiesel with diesel) and, accordingly, to meet the mitigation action by increased biofuel, this dissolution needs to evolve so it can meet the main goal of NPCC. That is, the NPPB needs to expand its goals considering the scale of sustainable use of exhaustible resources, such as diesel. For this, the contribution of ecological economics proposes a limit of scale in production, because it recognizes that natural resources (the Earth) are finite. And when dealing with a finite and polluting resource as petroleum and its derivatives, limits of their use scales is the elementary step for the process of replacement for a renewable resource. The NPCC has established eleven actions to reduce GHG emissions, but not as a way to achieve them. In this context, this work aims to estimate the need for blending biodiesel with diesel oil by 2020 on the goals of GHG mitigation of NPCC considering limits to the expansion of the use of diesel.

Recognizing that the goals of reducing carbon dioxide by 2020 boundaries converge on the issue, just to the emitting source, you can find the levels of mixture of diesel/biodiesel based on the future demand for this type of fuel. To estimate the future demand for diesel, it was used the Box-Jenkins methodology, and emissions of carbon dioxide were estimated by the top-down method. Four scenarios were constructed from the estimates, two which con-

\footnotetext{
${ }^{1}$ The terminology used in Brazil follows this naming, where B5 is 5\% blend of biodiesel in diesel, $\mathrm{B} 10$ is $10 \%$ biodiesel blend in diesel, where $\mathrm{Bn}$ is $\mathrm{n} \%$ mixture of biodiesel and diesel.
} 
sider the main goal of reducing emissions in the range of $36.1 \%$ to $38.9 \%$ and other two are based on the mitigation action by increase of biofuels which limiting emissions between 48 to 60 million $\mathrm{tCO}_{2}$.

This paper contains five subsequent chapters. The second chapter refers to the theoretical part, showing how natural resources were seen by mainstream economists and narrowing the discussion of the environment recognition as a necessary whole for the economy existence [ecological]. The third chapter is formed by the methodological and statistical parts, restrained by the top-down methodology to estimate the carbon dioxide emission per sources of energy fuel, using the Box-Jenkins methodology for predicting future series from a time series and by the procedures for the construction of biodiesel blend scenarios. The fourth chapter is the presentation and discussion of the results, which are consistent with the theoretical approach of ecological economics. Finally, there are the conclusion of the paper and the references used.

\section{SCALE OF CONSUMPTION: AN ECOLOGICAL ECONOMICS APPROACH}

In economics there are three complex and distinct strands, which discuss the relationship between economics and environment; they are: environmental economics (or pollution), natural resource economics and ecological economics. The difference between them is that the first two are subareas of neoclassical economics and do not consider their biosphere, both consider the environment as an appendix of economic-activity, which is still seen as the dominant throughout. The environmental economics (or pollution) is a direct offshoot of the neoclassical welfare and public goods. The economics of natural resources deals with aspects related to the extraction and depletion of natural resources over time (CAVALCANTI, 2010, p.56; DALY, 2010, p.7).

Ecological economics differs from both discussions presented on the environment, which originate from the traditional economics. The great forerunner of ecological economics is Nicholas Georgescu-Roegen, who made the critical mechanism and the design of the economic process as circular and isolated from nature (CECHIN, 2010, p.44). The concept of ecological economics is given, precisely, for contesting the traditional base.

Ecological economics believes that the economy is an open subsystem of a much larger system, that is finite and does not increase, physically closed, even though it's open for solar energy (CECHIN; VEIGA, 2010, p.33). The human economics is seen as a subset of a larger biotic system which is the nature, and it's subjected to this in one way or another. The changes that occur in the real economy are irreversible.

The production system transforms raw materials and natural resources into products that society values. However, this transformation necessarily produces 
some kind of residue, which does not fall back into the production system. If the economy picks up quality resources from a natural source and returns residuals without any quality to nature, then it is not possible to treat the economy as an isolated cycle.

The economy-activity supply the economic system of material and energy, they undergo a process called throughput and turn into garbage or degraded material and energy. A transformation of matter and energy with low entropy (resources) on matter and energy with high entropy (garbage) occurs, as established in the laws of thermodynamics, which Georgescu used in the first economic analogies with physics. With that, it introduces the idea of irreversibility and limits on economic theory due to the second law of thermodynamics in contrast to the first law, specifically the law of entropy versus conservation of material. Georgescu was concerned with the development of an economic theory to introduce and translate the interrelationship between economy and nature (ROMEIRO, 2003, p.9).

From a systemic view of the relationship between economics and the environment considering the physical and ecological principles, ecological economists are questioning the Earth's cargo capacity (size), regarding the economy's sustainability face to the environmental impacts and growing demands for energy and materials due to the population growth. It's recognized, therefore, the existence of these boundaries as barriers to optimal functioning of the economy and, before that, the big question raised is the sustainable scale of economic activity.

The scale is the physical volume of throughput, material and energy flows taken from the environment as raw materials of low entropy that return as high entropy residuals. The optimal scale would be the one that aims sustainability, and to achieve this it would be needed the control of throughputs use. Within this perspective, ecological economics has three major objectives of policies that require instruments independent of each other, it's about the scale, allocation and distribution.

The Earth's cargo limit is imposed while the scale extraction of exhaustible resources increases. "This threatens to alter the Earth's capacity to sustain life". However economic agents create new technologies to adapt to the restrictions, "the unprecedented speed of change in technology and ecological degradation" requires creating new opportunities at a higher speed than the changes. "Since there is some limit to the speed" of cultural adaptation, it seriously demands a form of "slow down to the speed of change that is forcing the adaptations" (DALY; FARLEY, 2004, p.39).

The scale of it is the physical dimension of the economic subsystem, which is contained in an ecosystem that sustains it. The scale of economic activity takes into account population size and per capita use of resources. This becomes 
relevant when considering that ecosystems (physical basis), that supply goods and services, are finite. "The perspective of ecological economics is that there will be a maximum scale sustainable economic system with respect to the ecosystem" and such scale will be determined by comparing economic benefits with marginal environmental costs. After all, when considering the "economical' side "it cannot ignore the depreciation of natural assets". Greater economic production involves growth use of resources (soil, water, air, forests, biodiversity, climate stability etc.) (DALY; FARLEY, 2004; CAVALCANTI, 2010; SANTOS; CORREIO, 2011).

By recognizing the existence of optimal scale, this refers to the need of stopping the growth, which requires the distribution approach. First, the concern about the scale issues involving future generations or the intergenerational distribution. Second, the concern with social, ie, while the economy grows it deceives the low-income ones that the redistributions will come. Therefore, the distribution is the right proportion of the allocation of resources to different individuals (DALY; FARLEY, 2004, p.40).

Distribution is the division of the flow of resources, embodied in products, among people, ie, the distribution of resources among social actors in a fair (equitable). This does not occur by itself, through the market. However, when thinking about distribution, one should think about what will be left for the future generations, as well as for the other species that inhabit the planet (SANTOS; CORREIO, 2011).

The other point of view of ecological economics is about the allocation, and the division of the resources flow between different productive sectors. The allocation is efficient when it can channel resources accordingly with individual preferences and purchasing opportunities of economic agents, being determined by the prices. And such determination occurs under a given scale of production and distribution. So for the existence of an efficient allocation, the only aspect that worried the traditional economy, it's required a priori the resolution of the scale and distribution (SANTOS; CORREIO, 2011).

Ecological economists believe the human economics shifted from the moment in which the limiting factor for economic growth was the capital made by men, for a moment that the limiting factor is the natural capital. The stock that allows the flow of natural resources, such as forests and oil deposits, is considered natural capital, and it's evident that these are examples of growth limiting factors. Therefore, the enhanced resource exploration leads to its scarcity and the monetary or produced capital is not sufficient to reset them, resulting in a collapse of the economy itself (DALY, 1991, p.18). Given the environmental limits, ecological economics questions the idea of economic growth intrinsic to the model of traditional economics. Growth, on one hand, is 
limited by the finiteness of raw materials, and on the other hand, the planet is restricted by the capacity of processing waste.

\section{METHODS AND PROCEDURES}

To forecast the future demand for diesel, it was used the ARIMA (autoregressive integrated moving average), known as Box-Jenkins methodology. The prediction will establish the limits of the diesel oil to be consumed and then estimate the levels of biodiesel blending until 2020. To estimate the Box-Jenkins model was used the SPSS Statistics 17 . The variable used is the monthly data series of the diesel sales from distributors in Brazil, using cubic meters $\left(\mathrm{m}^{3}\right)$ as unit measure, for the period from January 2000 to September 2012. In this series, it was used the observations for the period from 2000 to 2011 to make future estimates, reserving the observations of the year 2012 for comparison with the predictions.

The $\mathrm{CO}_{2}$ emissions for diesel consumption in Brazil will be estimated using the IPCC ${ }^{2}$ methodology, the top-down method in which $\mathrm{CO}_{2}$ emissions are calculated from the fuel supply. In this case, $\mathrm{CO}_{2}$ emissions in tons will be estimated from the amount consumed in cubic meters of diesel oil. The GHG reduction amplitude established by NPCC will be the groundwork for the construction of two scenarios of diesel oil/biodiesel blending in Brazil. The primary information is to know the emission levels for diesel in 2005, because this factor will guide the mitigation measures until 2020. The calculations were developed in the Microsoft Office Excel 2010 software.

\subsection{Top-down and bottom-up methods}

The $\mathrm{CO}_{2}$ emissions originated from fuel combustion can be estimated using two methodologies of the IPCC: the reference approach or top-down, in which he uses the apparent consumption (or supply) of fuel for estimating carbon dioxide emissions; and the sectorial approach, or bottom-up, in which $\mathrm{CO}_{2}$ emissions are calculated from the final energy consumption of each sector, taking in consideration the type of equipment used and their yields (ROVÈRE; COSTA, 2004). These methodologies of the IPCC use inventory to estimate national emissions.

There is a debate in the literature between these main paradigms. The bottom-up holds that it's possible to achieve substantial reductions in emissions by promoting the efficient use of natural resources, yet slow, gradual and non-interventionist. The top-down supports quick and direct actions, through energy fees and restrictions to the energy use. Top-down policy is very attractive because of its simplicity that can minimize the risks of climate change. By con-

\footnotetext{
${ }^{2}$ Intergovernmental Panel on Climate Change.
} 
trast, the bottom-up approach is more economically efficient and can minimize the negative impact of an energy policy on the economic growth (ESTEBAN, FEIJOÓ and HERNANDEZ, 2003).

Countries in international meetings have decided to accept the bottom-up approach, but Brazil has followed the top-down method deciding to establish a baseline for reducing emissions until 2020, more tied to the establishment of an emission limit. Indeed, the top-down method was chosen, which has the advantage over other methods because it doesn't depend on detailed information about the use of fuel by the final user, or on the intermediate transformations of fuel for calculating the $\mathrm{CO}_{2}$ (BRAZIL/MCT, 2010). This method provides the conversion of all fuel consumption measures to a common unit.

Primarily the amount of apparent consumption of fuel (AC) in cubic meters $\left(\mathrm{m}^{3}\right)$ are transformed to energy consumption (EC) in terajoules (TJ), subsequently converted to tons of carbon dioxide $\left(\mathrm{tCO}_{2}\right)$. To find the power unit, it is necessary to use the conversion factor $\left(\mathrm{F}_{\text {conv }}\right)$ and the correction factor $\left(\mathrm{F}_{\text {corr }}\right)$ (ALVARES JR; LINKE, 2001). The conversion factor of diesel is 0.848 tep and the correction factor equivalent to 0.95 . Therefore, here is the first formula:

$$
E C=A C . F_{\text {conv }} .41,87 \cdot 10^{-3} \cdot F_{\text {corr }}
$$

With the energy consumption (EC) in terajoule, it's possible to obtain the quantity of carbon (QC) emitted in burning fuel in tons (tC). For this transformation, we need the emission factor $\left(\mathrm{F}_{\text {emis }}\right)$ of diesel fuel, which is equivalent to 20.2 tons of carbon per terajoules $(\mathrm{tC} / \mathrm{TJ})$. Then we have the following equation:

$$
Q C=E C . F_{\text {emiss }}
$$

Having the quantity of emitted carbon, the emissions of carbon dioxide $\left(\mathrm{ECO}_{2}\right)$, it's finally found. This transformation is in function of molecular weights, and $12 \mathrm{tC}$ corresponds to $44 \mathrm{tCO}_{2}$. Therefore, $1 \mathrm{tCO}_{2}$ is equal to $0.2727 \mathrm{tC}$. One can also estimate the diesel oil adjusted equation $\left(\mathrm{ECO}_{2} \mathrm{OD}\right)$. Resulting that for every $1 \mathrm{~m} 3$ of apparent consumption, it's emitted a respective amount in tons of $\mathrm{CO}_{2}$ per diesel oil.

$$
\begin{aligned}
\mathrm{ECO}_{2} & =Q C \cdot \frac{44}{12} \\
\mathrm{ECO}_{2} \mathrm{OD} & =C A \cdot 2,4983
\end{aligned}
$$

Emissions from the burning of biomass as fuel are considered null, because they are a result of the process of photosynthesis. According to the emission inventory of the Ministry of Science and Technology, renewable fuels do not generate liquid emissions, in other words, the emission from the biodiesel burning in a given time period is sequestered in the following period (BRAZIL/MCT, 2010). 


\subsection{Method Box-Jenkins}

The main component of the time series refers to the data stationarity, ie, how the series behaves in a systematic pattern within a given time period, usually one year for monthly data (SANTANA, 2003, p.377). A stochastic process is stationary when its average and its variance are constant over time (GUJARATI, 2006, p.639), or may not exhibit tendencies and shall be stable over time.

For the verification of the stationarity, it was calculated, first of all, the unit root test (or test of Dickey-Fuller). The existence of trend and seasonality are characteristics that make a non-stationary series. To verify the existence of these constraints, it was a test to detect the Cox-Stuart trend test and the KruskalWallis test were used to determine trend and seasonality respectively. Once identified the stationarity of the series, we performed a Box-Jenkins methodology.

According to Moretin and Toloi (2006, p.105), the strategy for constructing the model is based on an iterative cycle consisting of four stages: identification, estimation, verification and estimation. From these steps, the choice of model structure is based on its own data. In the identification process, the main tools used in the identification process of the model are the autocorrelation function $(\mathrm{ACF})$ and partial autocorrelation function (PACF), with their respective correlograms. These assist in determining orders of autoregressive process (p), moving average (q) and differences (d) (PELLEGRINI, 2000).

Once identified the model, its parameters must be estimated. The estimates found in the identification phase are used as initial values. At some point it is necessary to use an iterative procedure for estimating non-linear least squares. The parameter estimation is performed by maximum likelihood method (MORETIN; TOLOI, 2006, p.179).

Once the model is already estimated, it's time to verify if it suitably represents or not the data. This verification was made by the Box-Pierce test. This test checks if the residues are white noise, ie, if the errors are minimal. After the iterative cycle of identification, estimation and diagnosis, one can use the estimated model to do future predictions.

A widely used procedure is to identify more than one model that are estimated and verified, and then, choosing among those the models the one that presents the lower mean squared error (MSE), especially if the purpose is prediction (MORETIN; TOLOI, 2006, p.105). Some criteria for choosing the best model are the Bayesian Information Criterion (BIC), the Root Mean Square Error (RMSE), Mean Absolute Percentage Error (MAPE) and the criterion of parsimony. 


\subsection{Procedures of Construction of the Scenarios}

The construction of GHG mitigation scenarios for Brazil only consider the effluents of carbon dioxide from diesel burning and it's based on the main goal and on the mitigation actions of the NPCC. The main goal of NPCC aims to reduce between $36.1 \%$ and $38.9 \%$ of the emissions by 2020 comparing to those of 2005, which will allow doing two scenarios for emission limits with percentage goal. Among the NPCC mitigation actions, it will be specifically highlighted the action related to the reduction of about 48 to 60 million $\mathrm{tCO}_{2}$ until 2020 by increasing biofuels, in the particular case of this study, the biodiesel, building up two more scenarios for these amplitudes with physical limit of emissions.

As the main fuels used by the Brazilian economy are diesel and gasoline, and these still have renewable substitutes, we used only the participation of the diesel oil emission in 2005 (the base year of NPCC). Thus, it was possible to determine the diesel participation and therefore the mitigation goal. Not including gasoline, fuel that has ethanol as a substitute that mitigates emissions and it's renewable. In this case, it becomes necessary to do a specific study for the future mitigation from the gasoline emissions associated with hydrous ethanol and ether.

The four scenarios will present at which levels the diesel oil consumption scale would need to reduce in contrast to a higher consumption of biodiesel, which is a clean fuel. From the demand forecast for diesel from 2012 to 2020, we estimated the emission of carbon dioxide by the top-down method. We used this measure to check the possible emission levels in case of the biodiesel and diesel blending doesn't happen.

Therefore, there are nine years, from 2012 to 2020, to accomplish the percentage reduction of total emissions in 2005. In that time frame, it was considered a ratio of $11.11 \%$, increasing in arithmetic progression until $2020^{3}$. At the end of the period (in 2020), we expect the fulfillment of the $100 \%$ reduction target. The dissociation of the main goal between the years in arithmetic progression is called annual reduction (AR). By equating the national goal of reducing emissions from diesel in $2005\left(\mathrm{GRE}_{\mathrm{OD}}\right)$ with the goal of annual reduction (AR), it's found the level of emission to reduce per year (ERa), which for scenarios 1 and 2 are in percentage (5) and for scenarios 3 and 4 are in $\mathrm{tCO}_{2}(6)$.

$$
E R_{a}(\%)=A R(\%) \cdot G R E_{O D}(\%)
$$

\footnotetext{
${ }^{3}$ It was decided, in this work, to establish the way of $\mathrm{CO}_{2}$ reduction using arithmetic progression, considering that each year from 2012 to 2020 is decreased the same percentage of primary goal. But that does not stop other ways of reduction can be performed.
} 


$$
E R_{a}\left(t C O_{2}\right)=A R(\%) \cdot G R E_{O D}\left(t C O_{2}\right)
$$

The emissions to be reduced per year (ERa) when subtracted with the national emission for diesel by $2005\left(\mathrm{E}_{\mathrm{OD}}\right)$ provides the annual emission limit $\left(\mathrm{EL}_{\mathrm{OD}}\right)$ in $\mathrm{tCO}_{2}$ (7) and (8). After that, it was determined the diesel consumption limit $\left(\mathrm{CL}_{\mathrm{OD}}\right)$ in $\mathrm{m}^{3}$ from the emission factor $\left(\mathrm{EF}_{\mathrm{OD}}=2.4983\right.$ $\mathrm{tCO}_{2}$ ) of this fuel (9).

$$
\begin{gathered}
E L_{O D}\left(t C O_{2}\right)=E_{O D}\left(t C O_{2}\right)-\left[E_{O D}\left(t C O_{2}\right) \cdot E R_{a}(\%)\right] \\
E L_{O D}\left(t C O_{2}\right)=E_{O D}\left(t C O_{2}\right)-E R_{a}\left(t C O_{2}\right) \\
C L_{O D}\left(m^{3}\right)=E L_{a}\left(t C O_{2}\right) / E F_{O D}
\end{gathered}
$$

The estimated need for diesel $\left(\mathrm{N}_{\mathrm{OD}}\right)$ is the forecasted series from 2012 to 2020 (Box-Jenkins method) for petroleum diesel. As biodiesel is the direct substitute of diesel oil, their blending will meet the demand need of this particular type of fuel. With the diesel consumption limit $\left(\mathrm{CL}_{\mathrm{OD}}\right)$ already estimated, then subtracted from the energy requirement for diesel predicted $\left(\mathrm{N}_{\mathrm{OD}}\right)$, one gets the need for biodiesel $\left(\mathrm{N}_{\mathrm{BD}}\right)$ to meet the possible demand (10). The need for biodiesel $\left(\mathrm{N}_{\mathrm{BD}}\right)$ as a function of the estimated need of diesel $\left(\mathrm{N}_{\mathrm{OD}}\right)$ provides the percentage of biodiesel and diesel oil blending $\left(\mathrm{B}_{\mathrm{BD} / \mathrm{OD}}\right)$ (11), which is essential to accomplish the annual carbon dioxide reduction.

$$
\begin{gathered}
N_{B D}\left(m^{3}\right)=N_{O D}\left(m^{3}\right)-C L_{O D}\left(m^{3}\right) \\
B_{B D / O D}(\%)=N_{B D}\left(m^{3}\right) / N_{O D}\left(m^{3}\right)
\end{gathered}
$$

\section{RESULTS AND DISCUSSION}

The diesel consumption in Brazil has been increasing from 2000 to 2011, with a geometric growth rate of $3.27 \%$, from a consumption of 35.1 million $\mathrm{m}^{3}$ in 2000 to 52.2 million $\mathrm{m}^{3}$ in the last year. The first procedure was to check the stationarity of the series.

To check the existence of tendency in the series, we applied the Cox-Stuart test, with a significance level of $\alpha=5 \%$ and taking 144 observations, getting $\mathrm{c}=72$ and $\mathrm{n}=72$. The pairs with positive signs $\left(Z_{i}<Z_{i+c}\right)$ were $T_{2}=71$, the negative pairs $\left(\mathrm{Z}_{\mathrm{i}}>\mathrm{Z}_{\mathrm{i}+\mathrm{c}}\right)$ were $T_{1}=1$. Therefore, the hypothesis that the series has tendency is accepted, as the number of pairs is different (Table 1).

To check the existence of seasonality, we used the Kruskal-Wallis test for $N=144, k=12$ and $n_{j}=12$. The statistics presented KW distribution equivalent to 94.437 and the tabulated value of $\chi_{11 ; 0,05}^{2}=19,6751$, as the KW distribution is greater than the value of chi-square, indicating that the series has seasonality. 
The test augmented Dickey-Fuller (unit root) in level with intercept confirmed the hypothesis of non-stationarity at a significance of $1 \%$ of the series of oil consumption in Brazil. But to make the first difference obtained a stationary series for all models. For the test, the calculated value for $\tau$ $\left(\tau_{c a l c}=-15,75\right)$ is less than the critic value $\left(\tau_{D F}=-4,02\right)$ at a significance level of $1 \%$, rejecting the hypothesis of non-stationarity (Table 2 ).

As the model assumes stationarity, the series was differentiated once to eliminate the trend component and lagged in one period to eliminate seasonality (Figure 1). The linearization was not efficient in terms of stationarity. Thus, for the identification of the model will be used with a regular difference and a seasonal difference, corresponding to the orders $d=1$ and $D=1$, respectively.

Table 1

Cox-Stuart and Kruskal-Wallis Tests for series of diesel consumption in Brazil

\begin{tabular}{|c|c|c|c|}
\hline \multicolumn{2}{|c|}{ Cox-Stuart } & \multicolumn{2}{|c|}{ Kruskal-Wallis } \\
\hline Pairs & Frequencies & Months & Mean Rank \\
\hline \multirow{3}{*}{ Negative Differences } & & 1 & 22,8333 \\
\hline & 1 & 2 & 41,4167 \\
\hline & & 3 & 44,8333 \\
\hline \multirow[t]{2}{*}{ Positive Differences } & 71 & 4 & 38,5000 \\
\hline & & 5 & 62,2500 \\
\hline \multirow[t]{2}{*}{ Total } & 72 & 6 & 60,9167 \\
\hline & & 7 & 59,0000 \\
\hline \multirow[t]{5}{*}{ Positive } & & 8 & 81,0000 \\
\hline & & 9 & 105,5833 \\
\hline & & 10 & 99,2500 \\
\hline & & 11 & 122,2500 \\
\hline & & 12 & 132,1667 \\
\hline Teste Z & $-8,132$ & Chi-Square & 94,437 \\
\hline p-value (2-tailed) & $0,000^{*}$ & p-value KW & $0,000^{*}$ \\
\hline
\end{tabular}

* Significant at $1 \%$.

Source: Result from the research starting on ANP's data (2012).

For series of Brazil, in ACF, among the first three correlations, the lag 1 is the only significant one, indicating to the regular part a $M A(q)=1$ or $M A(q)=2$ (Figure 1). And yet, to the seasonal part, the lag 24 proved to be significant, suggesting an $M A(Q)=1$. About the PACF, the lags 1 and 2 were significant, indicating both an $A R(p)=1$ as an $A R(p)=2$, for the regular part. The seasonal part, of the PACF had lags 12 and 24 significantly equal to zero, equivalent to an $A R(P)=0$. Therefore, the models suggested are: $\operatorname{SARIMA}(2,1,1)(0,1,1)_{12}$ and 
$\operatorname{SARIMA}(2,1,2)(0,1,1)_{12}$. To choose the best model were observed BIC criteria and parsimony (Table 3 ), as well as witnessed the behavior of residues.

Table 2

Augmented Dickey-Fuller Test for series of diesel consumption in Brazil

\begin{tabular}{|c|c|c|c|c|c|c|}
\hline & \multirow{2}{*}{ Model } & \multirow{2}{*}{ Variable } & \multirow{2}{*}{ ADF } & \multicolumn{3}{|c|}{ Critical Value } \\
\hline & & & & $1 \%$ & $5 \%$ & $10 \%$ \\
\hline \multirow{3}{*}{ In level } & with intercept & OD & $-2,8598^{\text {ns }}$ & $-3,4743$ & $-2,8805$ & $-2,5768$ \\
\hline & with intercept and tend & OD & $-5,8425^{\star}$ & $-4,0208$ & $-3,4399$ & $-3,1441$ \\
\hline & without intercept and tend & OD & $0,2189^{*}$ & $-2,5791$ & $-1,9419$ & $-1,6168$ \\
\hline \multirow{3}{*}{$\begin{array}{c}1 \text { st } \\
\text { difference }\end{array}$} & with intercept & OD & $-15,7962^{*}$ & $-2,5792$ & $-1,9419$ & $-1,6168$ \\
\hline & with intercept and tend & OD & $-15,7970^{*}$ & $-3,4746$ & $-2,8806$ & $-2,5768$ \\
\hline & without intercept and tend & OD & $-15,7577^{*}$ & $-4,0212$ & $-3,4401$ & $-3,1442$ \\
\hline
\end{tabular}

Obs.: number of diferences $=153$

* -Significant at 1\%, ns - not significant at $1 \%$.

Source: Result from the research starting on ANP's data (2012).

Figure 1

Correlogram of the differentiated series of diesel consumption in Brazil, 2000-2011

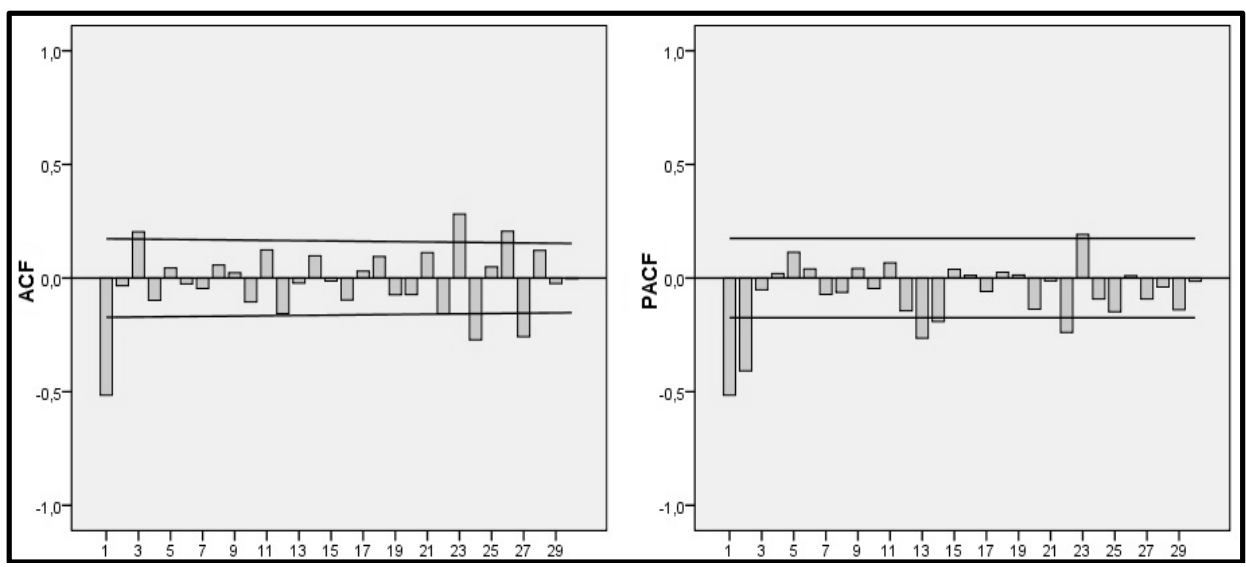

Source: Result from the research starting on ANP's data (2012).

When evaluating the models through $\mathrm{R}^{2}$, the variations in the parameters I and II of the model are explaining approximately $91 \%$ of the variations of the diesel fuel series. Observing the Bayesian information criterion (BIC), the model I performs best, in this case we seek to minimize the criterion. Also considering the parsimony criterion, the model $\mathrm{I}$ is indicated for having the smallest number of parameters in comparison to model II. Therefore, the model I is described as: 


$$
(1+0,644)(1-B)^{1}(1+0,389)(1-B)^{2}\left(1-B^{12}\right)^{1} Z_{t}=(1-0,175 B)\left(1-0,816 B^{12}\right) a_{t}
$$

Table 3

Suggested models to the diesel series in Brazil, 2000-2011

\begin{tabular}{|c|c|c|c|c|c|c|c|}
\hline Model & Variable & Coefficients & Test $t$ & $p$-value & $\mathbf{R}^{2}$ & $\mathrm{BIC}$ & Box-Pierce \\
\hline $\mathrm{I}$ & $A R(1)$ & $-0,644$ & $-3,718$ & $0,000^{*}$ & \multirow{4}{*}{0,910} & \multirow{4}{*}{23,971} & $Q(18)=15,069$ \\
\hline \multirow{4}{*}{$\begin{array}{c}\text { SARIMA } \\
(2,1,1)(0,1,1)_{12}\end{array}$} & $A R(2)$ & $-0,389$ & $-3,184$ & $0,002^{*}$ & & & $\chi_{14}^{2}=23,685$ \\
\hline & MA (1) & 0,175 & 0,934 & $0,352^{\text {ns }}$ & & & $p$-valor $=0,373^{\text {ns }}$ \\
\hline & SMA (1) & 0,816 & 6,892 & $0,000^{*}$ & & & \\
\hline & $A R(1)$ & $-0,195$ & $-0,661$ & $0,510 \mathrm{~ns}$ & & & \\
\hline II & $A R(2)$ & $-0,329$ & $-2,377$ & $0,019^{* *}$ & & & $Q(18)=13,785$ \\
\hline SARIMA & MA (1) & 0,638 & 2,151 & $0,033^{* *}$ & 0,911 & 24,008 & $\chi_{13}^{2}=22,362$ \\
\hline \multirow[t]{2}{*}{$(2,1,2)(0,1,1)_{12}$} & MA (2) & $-0,347$ & $-1,798$ & $0,075^{\star \star *}$ & & & \multirow[t]{2}{*}{$p$-valor $=0,389^{n s}$} \\
\hline & SMA (1) & 0,819 & 6,821 & $0,000^{*}$ & & & \\
\hline
\end{tabular}

* - significant at 1\%; ** - significant at 5\%; *** - significant at $10 \%{ }^{\text {ns }}$ - not significant.

Source: Search results based on data from the ANP (2012).

To verify that the chosen model adequately represents the diesel consumption data, the residues analysis was made through the correlogram and the BoxPierce test. For the Model I, the statistic test of Box-Pierce Q(18) of Brazil series is smaller than the tabulated chi-square statistic $\left(\chi_{14}^{2}\right)$. Therefore $Q(18)$ is statistically significant. And the residues correlogram presents white noise behavior, ie, statistically equal to zero (Figure 2). Therefore, the model $\operatorname{SARIMA}(2,1,1)(0,1,1)_{12}$ is appropriate to make forecasts.

The series of forecasted values from October 2012 to December 2020 for Brazil and the observations of the original series until September 2012 are shown in Figure 3. The expected series from 2012 to 2020 showed a geometric growth rate of $3.23 \%$ over the period, with a prediction of consumption of 55.156 million $\mathrm{m}^{3}$ in the first year of estimation and 70.729 million $\mathrm{m}^{3}$ in 2020 . This forecast sets up the national need for this type of fuel, as well as for those energies able to replace it, such as biodiesel.

The Ministry of Mines and Energy (MME) published, in 2007, a report with estimates for the Brazilian energy matrix by 2030 showing that among the ultimate sources of energy (petroleum, electricity, natural gas, coal, firewood and charcoal, sugarcane products, biodiesel, etc.), petroleum products account for approximately $37 \%$ of final energy consumption in 2020 (BRAZIL/MME, 2007, p.103). That is, the expectation is that the hegemony of oil will postpone the next 20 years in the Brazilian energy matrix. 
Figure 2

Correlogram of the residuals of the model SARIMA $\llbracket(2,1,1)(0,1,1) \rrbracket \_12$

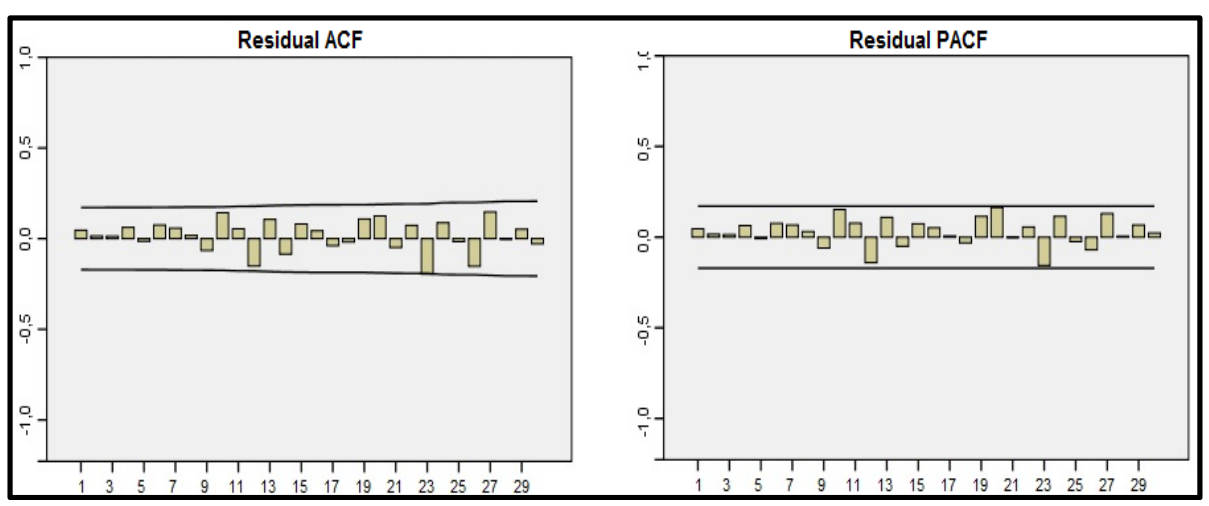

Source: Results of the search.

Figure 3

Original series and forecasted series of the consumption of diesel in Brazil, January/2000 to December/2020

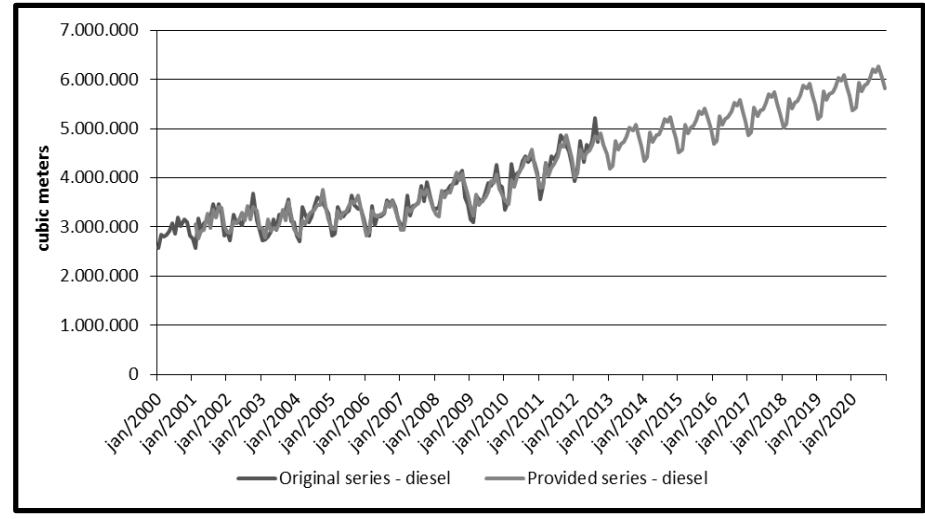

Source: Results of the search.

Thus, the main issue rose by ecological economics, regarding the limits of scale, will be applied to the construction of scenarios of biodiesel / diesel oil blending, whose intention is to limit the consumption of the petroleum diesel. A mathematical framework was used, supported by NPCC, in search of visualizing scenarios with a decreasing scale of consumption of diesel and a larger scale of its renewable substitute, the biodiesel.

When the NPCC establishes quantities to reduce emissions of carbon dioxide, it's setting emission limits. That is, one can emit, but to certain preset level. This creates a maximum scale of emission, as Georgescu-Roegen and 
other ecological economists warned. For the economic agents meet the goals in the competitive market, will be required greater control of public authorities, so the mitigation leads to an environmental contribution, which wouldn't allow to degrade or reduces the existing natural stocks any further.

Starting from the series provided for diesel to Brazil, four scenarios were constructed to estimate the required percentage of biodiesel blend to the 2020. It is known a priori that a study conducted by FGV Projects (2010) predicts a blend B20 or $20 \%$ of blending for the year 2020, with a production of biodiesel estimated at approximately 14.5 million $\mathrm{m}^{3}$. The study of FGV Projects doesn't present the methodology for estimation, so one cannot make a direct comparison with the present work in which we applied the Box-Jenkins methodology for forecasting the consumption of diesel fuel and is rooted in the NPCC goals. Knowing this, it becomes necessary to estimate the required blending of exhaustible/renewable able to mitigate emissions, in this case, those of 2005.

The first two scenarios are based on the national goal of reducing $\mathrm{CO}_{2}$ emissions in the amplitude of $36.1 \%$ to $38.9 \%$ by 2020 . Therefore, these limits express the percentage goal to reduce emissions. To comply with this entire goal, it is considered that each system responsible for the emissions of gaseous effluents should take such goal amplitude. Dealing only with the energy sector and vehicle fuels subsector, one has a scalar use of diesel.

The NPCC also advanced to establish actions to specific systems to make $\mathrm{CO}_{2}$ mitigation, this study limited the action of increasing biofuel to reduce between 48 million to 60 million $\mathrm{tCO}_{2}$. As the focus is mitigating $\mathrm{CO}_{2}$ emissions of diesel oil, the increase will be focused by biodiesel. Thus, these physical limits to reduce emissions in the simulations will constitute the third and fourth scenarios.

An important indicator for determining the mitigation goals for diesel oil was to utilize the emissions participation only of diesel in 2005 to establish a percentage goal and a physical goal to be reduced until 2020. The emission of carbon dioxide in Brazil by the consumption of exhaustible fuels diesel and petrol in 2005 amounted to 151.8 million in $\mathrm{tCO}_{2}$. The use of diesel oil was responsible for most of the emissions (64.45\%), equivalent to $97.851 \mathrm{tCO}_{2}$. To mitigate emissions of diesel in 2005, this study considers that this effort could have started in 2012, ie, that means, the mitigation is gradually done until 2020, otherwise a greater effort will be required for the year of the goal compliance.

The simulations of scenario 1 (Table 4) show that the biodiesel blending needs to evolve from B31 (31\% blended) in 2012 to B58 (58\% of blend) in 2020, from 17.001 million $\mathrm{m}^{3}$ of biodiesel to 40.675 million $\mathrm{m}^{3}$ respectively (geometric growth rate - GGR of $11.56 \%$ over the period). For Brazil to be able of accomplishing its goal of reducing emissions by $36.1 \%$, it will need this evolution of biodiesel and diesel oil blending to achieve a $23.3 \%$ reduction of 
2005 emissions caused by the use of the latter. Meanwhile, predicts a decreasing demand for pure diesel oil, a decrease of $2.94 \%$ in the 2012 to 2020 period, whose amount will fall from 38.1 million $\mathrm{m}^{3}$ to 30.0 million $\mathrm{m}^{3}$.

\section{Table 4}

Scenario 1 with a goal of reducing the percentage of $\mathrm{CO}_{2}$ for diesel oil

\begin{tabular}{|c|c|c|c|c|c|c|c|c|}
\hline \multirow[t]{3}{*}{2005} & \multirow{2}{*}{$\begin{array}{c}\begin{array}{c}C_{\text {OD+GASOL }} \\
\left(\mathrm{m}^{3}\right)\end{array} \\
62.720 .645 \\
\end{array}$} & \multirow{2}{*}{$\begin{array}{c}\mathbf{C}_{\text {OD }}\left(\mathbf{m}^{3}\right) \\
39.167 .155\end{array}$} & \multirow{2}{*}{\multicolumn{2}{|c|}{$\begin{array}{c}E_{O D+G A S O L} \\
\left(\mathbf{t C O}_{2}\right) \\
151.820 .059\end{array}$}} & \multirow{3}{*}{  } & \multirow{3}{*}{$\begin{array}{c}\begin{array}{c}\text { Part. EOD } \\
\text { (\%) }\end{array} \\
64,45 \% \\
\text { CL }_{\text {OD }}\left(\mathrm{m}^{3}\right)\end{array}$} & \multirow{3}{*}{$\begin{array}{c}\text { GRE } \\
(\%) \\
23,27 \% \\
N_{B D}\left(\mathbf{m}^{3}\right)\end{array}$} & \multirow{3}{*}{$\begin{array}{c}\mathrm{EF}_{\mathrm{OD}} \\
\left(\mathrm{tCO}_{2}\right) \\
2,4983 \\
\mathrm{~B}_{\mathrm{BD} / \mathrm{OD}} \\
(\%)\end{array}$} \\
\hline & & & & & & & & \\
\hline & $\mathrm{N}_{\mathrm{OD}}\left(\mathrm{m}^{3}\right)$ & $\mathrm{E}_{\mathrm{OD}}\left(\mathrm{tCO}_{2}\right)$ & AR (\%) & ERa (\%) & & & & \\
\hline 2012 & 55.156 .070 & 137.796 .610 & $11,11 \%$ & $2,58 \%$ & 95.321 .992 & 38.154 .687 & 17.001 .384 & $31 \%$ \\
\hline 2013 & 56.515 .535 & 141.192 .965 & $22,22 \%$ & $5,17 \%$ & 92.792 .539 & 37.142 .218 & 19.373 .316 & $34 \%$ \\
\hline 2014 & 58.546 .152 & 146.266 .064 & $33,33 \%$ & $7,75 \%$ & 90.263 .086 & 36.129 .750 & 22.416 .402 & $38 \%$ \\
\hline 2015 & 60.576 .772 & 151.339 .170 & $44,44 \%$ & $10,34 \%$ & 87.733 .633 & 35.117 .282 & 25.459 .490 & $42 \%$ \\
\hline 2016 & 62.607 .392 & 156.412 .275 & $55,55 \%$ & $12,92 \%$ & 85.204 .180 & 34.104 .814 & 28.502 .578 & $46 \%$ \\
\hline 2017 & 64.638 .012 & 161.485 .380 & $66,66 \%$ & $15,51 \%$ & 82.674 .728 & 33.092 .346 & 31.545 .666 & $49 \%$ \\
\hline 2018 & 66.668 .632 & 166.558 .485 & $77,77 \%$ & $18,09 \%$ & 80.145 .275 & 32.079 .878 & 34.588 .754 & $52 \%$ \\
\hline 2019 & 68.699 .252 & 171.631 .591 & $88,88 \%$ & $20,68 \%$ & 77.615 .822 & 31.067 .410 & 37.631 .843 & $55 \%$ \\
\hline 2020 & 70.729 .872 & 176.704 .696 & $100,00 \%$ & $23,27 \%$ & 75.084 .092 & 30.054 .030 & 40.675 .842 & $58 \%$ \\
\hline
\end{tabular}

Source: Authors. Legend: $\mathrm{COD}+\mathrm{GASOL}\left(\mathrm{m}^{3}\right)$ - national consumption of gasoline and diesel fuel; $\operatorname{COD}\left(\mathrm{m}^{3}\right)$ - national consumption of diesel oil; EOD + GASOL $\left(\mathrm{tCO}_{2}\right)$ - national emission for diesel and gasoline; $\mathrm{EOD}\left(\mathrm{tCO}_{2}\right)$ - national $\mathrm{CO}_{2}$ emission for diesel; Part. EOD (\%) percentage share of the national emission diesel; GREOD (\%) - goal of reducing emissions of diesel; EFOD - emission factor of diesel oil; NOD $\left(\mathrm{m}^{3}\right)$ - need for diesel; AR (\%) - annual reduction in arithmetic progression with ratio and first term equal to $11.11 \%$; ERa (\%) emissions to reduce per year; ELOD $\left(\mathrm{tCO}_{2}\right)$ - emission limit of diesel; CLOD $\left(\mathrm{m}^{3}\right)$ consumption limit of diesel oil; NBD $\left(\mathrm{m}^{3}\right)$ - need for biodiesel; and BBD/OD (\%) percentage blend of biodiesel to diesel.

In scenario 2 , whose national goal is to reduce $38.9 \%$ of the emissions and considering the liability of $64.45 \%$ for diesel emissions in 2005 , is necessary to reduce $25.07 \%$ of 2005 emissions by 2020 (Table 5). The simulations show that the need for biodiesel will have a geometric growth of $11.72 \%$ in the period from 2012 to 2020, with the blending evolving from B31 in 2012 to B59 in 2020. To do so, it will require higher amount of biodiesel, around 17.078 million $\mathrm{m}^{3}$ in 2012 to 41.382078 million $\mathrm{m}^{3}$ in 2020 . Note that in scenario 2 the blending in 2020 is $1 \%$ above the blending (B59) of scenario 1 (B58), but this tiny difference enhances a difference of $1.73 \%$ more biodiesel in scenario 2 . This insignificant difference makes the demand for pure diesel oil even more decreasing at a geometric rate of $-3.20 \%$ in the period from 2012 to 2020 , decreasing from 38.077 million $\mathrm{m}^{3}$ in 2012 to 29.347 million $\mathrm{m}^{3}$ in 2020 . 
Table 5

Scenario 2 with percentage goal of reduction of $\mathrm{CO}_{2}$ for diesel oil

\begin{tabular}{|c|c|c|c|c|c|c|c|c|}
\hline \multirow[t]{2}{*}{2005} & $\begin{array}{c}\begin{array}{c}\mathrm{C}_{\text {OD+GASOL }} \\
\left(\mathrm{m}^{3}\right)\end{array} \\
62.720 .645\end{array}$ & $\begin{array}{c}\begin{array}{c}\mathbf{C}_{\text {op }} \\
\left(\mathbf{m}^{3}\right)\end{array} \\
39.167 .155\end{array}$ & \multicolumn{2}{|c|}{$\begin{array}{c}\text { EOD+GASOL }_{\text {OD }}\left(\mathbf{t C O}_{2}\right) \\
151.820 .059\end{array}$} & \multirow{2}{*}{$\begin{array}{c}\begin{array}{c}\mathrm{EOD} \\
\left(\mathrm{tCO}_{2}\right)\end{array} \\
97.851 .445 \\
\begin{array}{c}\mathrm{EL} \text { OD } \\
\left(\mathrm{tCO}_{2}\right)\end{array}\end{array}$} & \multirow{2}{*}{$\begin{array}{c}\begin{array}{c}\text { Part. E } \\
(\%)\end{array} \\
64,45 \% \\
\mathrm{CL}_{\text {OD }}\left(\mathrm{m}^{3}\right)\end{array}$} & \multirow{2}{*}{$\begin{array}{c}\begin{array}{c}\text { GRE } \\
(\%)\end{array} \\
25,07 \% \\
N_{\text {BD }}\left(\mathbf{m}^{3}\right)\end{array}$} & \multirow{2}{*}{ 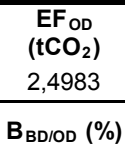 } \\
\hline & $\mathrm{N}_{\mathrm{OD}}\left(\mathrm{m}^{3}\right)$ & $\mathrm{E}_{\mathrm{OD}}\left(\mathrm{tCO}_{2}\right)$ & AR (\%) & $\begin{array}{l}\text { ERa } \\
(\%)\end{array}$ & & & & \\
\hline 2012 & 55.156 .070 & 137.796 .610 & $11,10 \%$ & $2,78 \%$ & 95.128 .255 & 38.077 .139 & 17.078 .931 & $31 \%$ \\
\hline 2013 & 56.515 .535 & 141.192 .965 & $22,20 \%$ & $5,57 \%$ & 92.405 .065 & 36.987 .124 & 19.528 .411 & $35 \%$ \\
\hline 2014 & 58.546 .152 & 146.266 .064 & $33,30 \%$ & $8,35 \%$ & 89.681 .875 & 35.897 .108 & 22.649 .044 & $39 \%$ \\
\hline 2015 & 60.576 .772 & 151.339 .170 & $44,40 \%$ & $11,13 \%$ & 86.958 .686 & 34.807 .093 & 25.769 .680 & $43 \%$ \\
\hline 2016 & 62.607 .392 & 156.412 .275 & $55,50 \%$ & $13,91 \%$ & 84.235 .496 & 33.717 .077 & 28.890 .315 & $46 \%$ \\
\hline 2017 & 64.638 .012 & 161.485 .380 & $66,60 \%$ & $16,70 \%$ & 81.512 .306 & 32.627 .061 & 32.010 .951 & $50 \%$ \\
\hline 2018 & 66.668 .632 & 166.558 .485 & $77,70 \%$ & $19,48 \%$ & 78.789 .116 & 31.537 .046 & 35.131 .586 & $53 \%$ \\
\hline 2019 & 68.699 .252 & 171.631 .591 & $88,80 \%$ & $22,26 \%$ & 76.065 .926 & 30.447 .030 & 38.252 .222 & $56 \%$ \\
\hline 2020 & 70.729 .872 & 176.704 .696 & $100,00 \%$ & $25,07 \%$ & 73.318 .203 & 29.347 .195 & 41.382 .677 & $59 \%$ \\
\hline
\end{tabular}

Source: Own elaboration.

In Figure 4 are more successfully observed the dynamics of increasing amounts of biodiesel to be demanded by the national economy from 2012 to 2020 in the context of limiting the consumption of diesel. And in turn, shows a decreasing tendency, because it contemplates one of the points of Ecological Economics in a smaller scale of use of exhaustible resources.

Figure 4

Scenario 1 and 2, biodiesel blend in diesel oil in Brazil

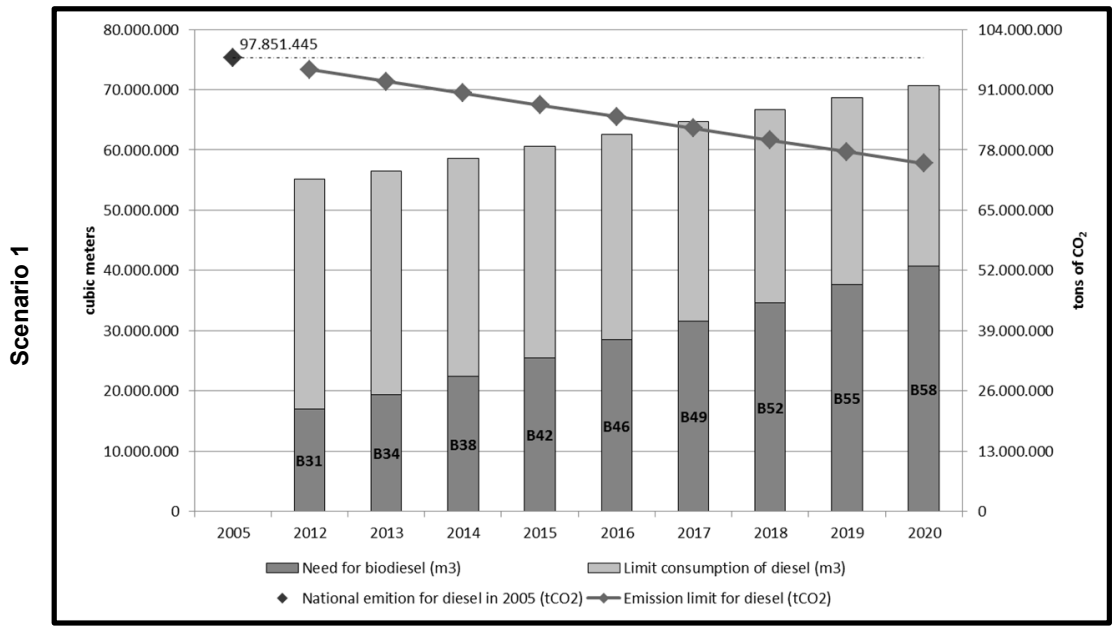


Figure 4 (continue)

Scenario 1 and 2, biodiesel blend in diesel oil in Brazil

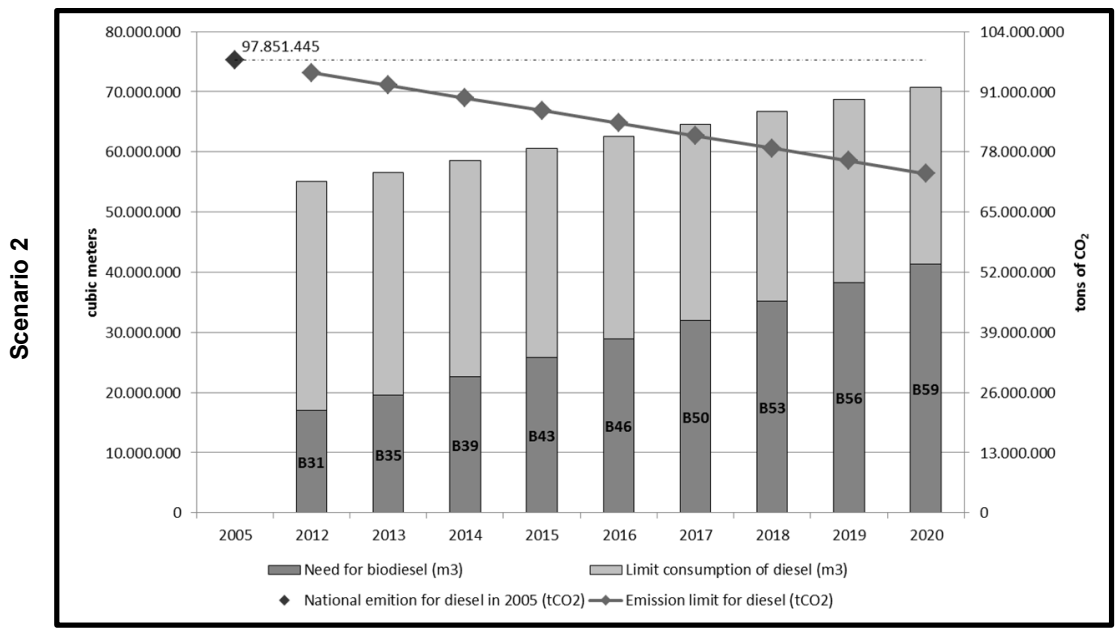

Source: Own elaboration.

The third and fourth scenarios consider the physical limitation of $\mathrm{CO}_{2}$ emissions. In this case the levels to be mitigated by the increasing of biofuels are respectively 48 million and 60 million $\mathrm{tCO}_{2}$. Being diesel responsible for $64.45 \%$ of emissions in 2005, the physical goals are 30.937 million $\mathrm{tCO}_{2}$ in scenario 3 and 38.671 million $\mathrm{tCO}_{2}$ in scenario 4 , which should be mitigated by the increase of biodiesel and limiting the use of diesel oil.

The data show that in the third scenario the blending of biodiesel from 2012 to 2020 will be between $\mathrm{B} 31$ and B62, whose quantities of biodiesel are ranging from, respectively, 17,364,000 to 43,945,000 $\mathrm{m}^{3}$ (Table 6). A geometric growth of $12.3 \%$ in this period. In the fourth scenario, the forecasts reveal blends that start in 2012 with B32 to B67 in 2020 (Table 7). These levels of mixing show a growing need for biodiesel from 17.708 million $\mathrm{m}^{3}$ of biodiesel on 2012 to $47.041 \mathrm{~m}^{3}$ in 2020 (GGR equal to $12.93 \%$ during the period).

In the last two scenarios, the need for diesel fuel is decreasing in the period from 2012 to 2020, for considering the limitation of the use of non-renewable fuel as proposed by the Ecological Economics. In the third scenario, the forecast shows a decrease in the need for diesel of $4.20 \%$ in the period from 2012 to 2020. In the fourth scenario, the quantity of diesel shows a decrease of $5.54 \%$ in the period (Figure 5).

Therefore, in order that the Brazilian emissions by diesel reduce, given the biodiesel increment, it's required blends that evolve from blends of B31 to B32 in 2012 to blends between B58 and B67 in 2020, according the simulations of the fourth scenario. It is known that since January 2010 the Brazilian blend of 
biodiesel to diesel remains at 5\%. To achieve the levels of carbon dioxide mitigation undertaken in NPCC this blend would need an exponential growth unreachable, taken as a basis the current dissolution and the production model whose input is soybean oil.

Table 6

Scenario 3 with physical reduction target of $\mathrm{CO}_{2}$ into diesel fuel

\begin{tabular}{|c|c|c|c|c|c|c|c|c|}
\hline \multirow[t]{3}{*}{2005} & \multirow{2}{*}{$\begin{array}{c}\begin{array}{c}C_{\text {OD+GASOL }} \\
\left(\mathbf{m}^{3}\right)\end{array} \\
62.720 .645 \\
\end{array}$} & \multirow{2}{*}{$\begin{array}{c}\begin{array}{c}\mathbf{C}_{\mathrm{OD}} \\
\left(\mathbf{m}^{3}\right)\end{array} \\
39.167 .155 \\
\end{array}$} & \multirow{2}{*}{\multicolumn{2}{|c|}{$\begin{array}{c}\mathrm{E}_{\mathrm{OD}+\mathrm{GASOL}} \\
\left(\mathbf{t C O _ { 2 } )}\right. \\
151.820 .059\end{array}$}} & \multirow{3}{*}{$\begin{array}{c}\left.\begin{array}{c}\mathrm{E}_{\mathrm{OD}} \\
(\mathbf{t C O}\end{array}\right) \\
97.851 .445 \\
\left.\begin{array}{c}\mathrm{EL} O \mathrm{OD} \\
(\mathbf{t C O}\end{array}\right)\end{array}$} & \multirow{3}{*}{$\begin{array}{c}\begin{array}{c}\text { Part. E OD } \\
(\%)\end{array} \\
64,45 \% \\
\text { CL OD }^{\left(\mathrm{m}^{3}\right)}\end{array}$} & \multirow{3}{*}{$\begin{array}{c}\begin{array}{c}\text { GRE } \\
\left(\mathrm{tCO}_{2}\right) \\
30.937 .080\end{array} \\
\mathbf{N}_{\mathrm{BD}}\left(\mathbf{m}^{\mathbf{3}}\right)\end{array}$} & \multirow{3}{*}{$\begin{array}{c}\mathrm{EF} \text { oD } \\
\left(\mathrm{tCO}_{2}\right) \\
2,4983 \\
\mathrm{~B}_{\mathrm{BD} / \mathrm{OD}} \\
(\%)\end{array}$} \\
\hline & & & & & & & & \\
\hline & $N_{O D}\left(m^{3}\right)$ & $\mathrm{E}_{\mathrm{OD}}\left(\mathrm{tCO}_{2}\right)$ & AR (\%) & $\begin{array}{c}\mathrm{ERa} \\
\left(\mathrm{tCO}_{2}\right)\end{array}$ & & & & \\
\hline 2012 & 55.156 .070 & 137.796 .610 & $11,11 \%$ & 3.437 .110 & 94.414 .335 & 37.791 .377 & 17.364 .693 & $31 \%$ \\
\hline 2013 & 56.515 .535 & 141.192 .965 & $22,22 \%$ & 6.874 .219 & 90.977 .225 & 36.415 .600 & 20.099 .935 & $36 \%$ \\
\hline 2014 & 58.546 .152 & 146.266 .064 & $33,33 \%$ & 10.311.329 & 87.540 .116 & 35.039 .823 & 23.506 .330 & $40 \%$ \\
\hline 2015 & 60.576 .772 & 151.339 .170 & $44,44 \%$ & 13.748 .438 & 84.103 .006 & 33.664 .045 & 26.912 .727 & $44 \%$ \\
\hline 2016 & 62.607 .392 & 156.412 .275 & $55,55 \%$ & 17.185 .548 & 80.665 .897 & 32.288 .268 & 30.319 .124 & $48 \%$ \\
\hline 2017 & 64.638 .012 & 161.485 .380 & $66,66 \%$ & 20.622 .658 & 77.228 .787 & 30.912 .490 & 33.725 .522 & $52 \%$ \\
\hline 2018 & 66.668 .632 & 166.558 .485 & $77,77 \%$ & 24.059 .767 & 73.791 .677 & 29.536 .713 & 37.131 .919 & $56 \%$ \\
\hline 2019 & 68.699 .252 & 171.631 .591 & $88,88 \%$ & 27.496 .877 & 70.354 .568 & 28.160 .936 & 40.538 .316 & $59 \%$ \\
\hline 2020 & 70.729 .872 & 176.704 .696 & $100,00 \%$ & 30.937 .080 & 66.914 .364 & 26.783 .920 & 43.945 .952 & $62 \%$ \\
\hline
\end{tabular}

Source: Authors. Legend: $\mathrm{C}_{\mathrm{OD}}+\mathrm{GASOL}\left(\mathrm{m}^{3}\right)$ - national consumption of gasoline and diesel fuel; $\mathrm{C}_{\mathrm{OD}}$ $\left(\mathrm{m}^{3}\right)$ - national consumption of diesel oil; $\mathrm{E}_{\mathrm{OD}}+\mathrm{GASOL}\left(\mathrm{tCO}_{2}\right)$ - national emission for diesel and gasoline; $\mathrm{E}_{\mathrm{OD}}\left(\mathrm{tCO}_{2}\right)$ - national $\mathrm{CO}_{2}$ emission for diesel; Part. $\mathrm{E}_{\mathrm{OD}}(\%)$ - percentage share of the national emission diesel; GRE $\mathrm{OD}(\%)$ - goal of reducing emissions of diesel; $E_{O D}$ - emission factor of diesel oil; $\mathrm{N}_{\mathrm{OD}}\left(\mathrm{m}^{3}\right)$ - need for diesel; AR (\%) - annual reduction in arithmetic progression with ratio and first term equal to $11.11 \%$; ERa $\left(\mathrm{tCO}_{2}\right)$ - emissions to reduce per year; $E L_{O D}\left(\mathrm{tCO}_{2}\right)$ - emission limit of diesel; $\mathrm{CL}_{\mathrm{OD}}\left(\mathrm{m}^{3}\right)$ - consumption limit of diesel oil; $\mathrm{N}_{\mathrm{BD}}\left(\mathrm{m}^{3}\right)$ - need for biodiesel; and $\mathrm{B}_{\mathrm{BD} / \mathrm{OD}}(\%)$ - percentage blend of biodiesel to diesel.

Table 7

Scenario 4 with a goal of reducing physical $\mathrm{CO}_{2}$ for diesel oil

\begin{tabular}{|c|c|c|c|c|c|c|c|c|}
\hline \multirow[t]{2}{*}{2005} & \multirow{2}{*}{$\begin{array}{c}\begin{array}{c}C_{\text {OD+GASOL }} \\
\left(\mathrm{m}^{3}\right)\end{array} \\
62.720 .645 \\
N_{\text {OD }}\left(\mathrm{m}^{3}\right)\end{array}$} & \multirow{2}{*}{$\begin{array}{c}\begin{array}{c}\mathbf{C}_{\mathrm{OD}} \\
\left(\mathbf{m}^{3}\right)\end{array} \\
39.167 .155 \\
E_{\text {OD }}\left(\mathrm{tCO}_{2}\right)\end{array}$} & \multicolumn{2}{|c|}{$\begin{array}{c}\mathrm{E}_{\mathrm{OD}+\mathrm{GASOL}} \\
\left(\mathbf{t C O}_{\mathbf{2}}\right) \\
151.820 .059\end{array}$} & \multirow{2}{*}{$\begin{array}{c}\begin{array}{c}\text { EOD } \\
\left(\mathbf{t C O}_{2}\right)\end{array} \\
97.851 .445 \\
\text { EL OD } \\
\left(\mathbf{t C O}_{2}\right)\end{array}$} & \multirow{2}{*}{ 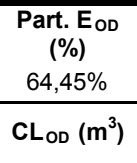 } & \multirow{2}{*}{$\begin{array}{c}\begin{array}{c}\mathrm{GRE}_{\mathrm{OD}} \\
\left(\mathrm{tCO}_{2}\right) \\
38.671 .350\end{array} \\
\mathbf{N}_{\mathrm{BD}}\left(\mathbf{m}^{3}\right)\end{array}$} & \multirow{2}{*}{$\begin{array}{c}\mathrm{EF} \text { oD } \\
\left.(\mathrm{tCO})_{2}\right) \\
2,4983 \\
\mathrm{~B}_{\mathrm{BD} / \mathrm{OD}} \\
(\%)\end{array}$} \\
\hline & & & AR (\%) & $\begin{array}{c}\mathrm{ERa} \\
\left(\mathrm{tCO}_{2}\right)\end{array}$ & & & & \\
\hline 2012 & 55.156 .070 & 137.796 .610 & $11,11 \%$ & 4.296 .387 & 93.555 .058 & 37.447 .433 & 17.708 .637 & $32 \%$ \\
\hline 2013 & 56.515 .535 & 141.192 .965 & $22,22 \%$ & 8.592 .774 & 89.258 .671 & 35.727 .711 & 20.787 .823 & $37 \%$ \\
\hline 2014 & 58.546 .152 & 146.266 .064 & $33,33 \%$ & 12.889 .161 & 84.962 .284 & 34.007 .990 & 24.538 .163 & $42 \%$ \\
\hline 2015 & 60.576 .772 & 151.339 .170 & $44,44 \%$ & 17.185 .548 & 80.665 .897 & 32.288 .268 & 28.288 .504 & $47 \%$ \\
\hline 2016 & 62.607 .392 & 156.412 .275 & $55,55 \%$ & 21.481 .935 & 76.369 .510 & 30.568 .546 & 32.038 .846 & $51 \%$ \\
\hline 2017 & 64.638 .012 & 161.485 .380 & $66,66 \%$ & 25.778 .322 & 72.073 .123 & 28.848 .824 & 35.789 .188 & $55 \%$ \\
\hline 2018 & 66.668 .632 & 166.558 .485 & $77,77 \%$ & 30.074 .709 & 67.776 .736 & 27.129 .103 & 39.539 .529 & $59 \%$ \\
\hline 2019 & 68.699 .252 & 171.631 .591 & $88,88 \%$ & 34.371 .096 & 63.480 .349 & 25.409 .381 & 43.289 .871 & $63 \%$ \\
\hline 2020 & 70.729 .872 & 176.704 .696 & $100,00 \%$ & 38.671 .350 & 59.180 .094 & 23.688 .111 & 47.041 .761 & $67 \%$ \\
\hline
\end{tabular}

Source: Own elaboration. 
Figure 5

Scenarios 3 and 4, biodiesel blend in diesel oil in Brazil
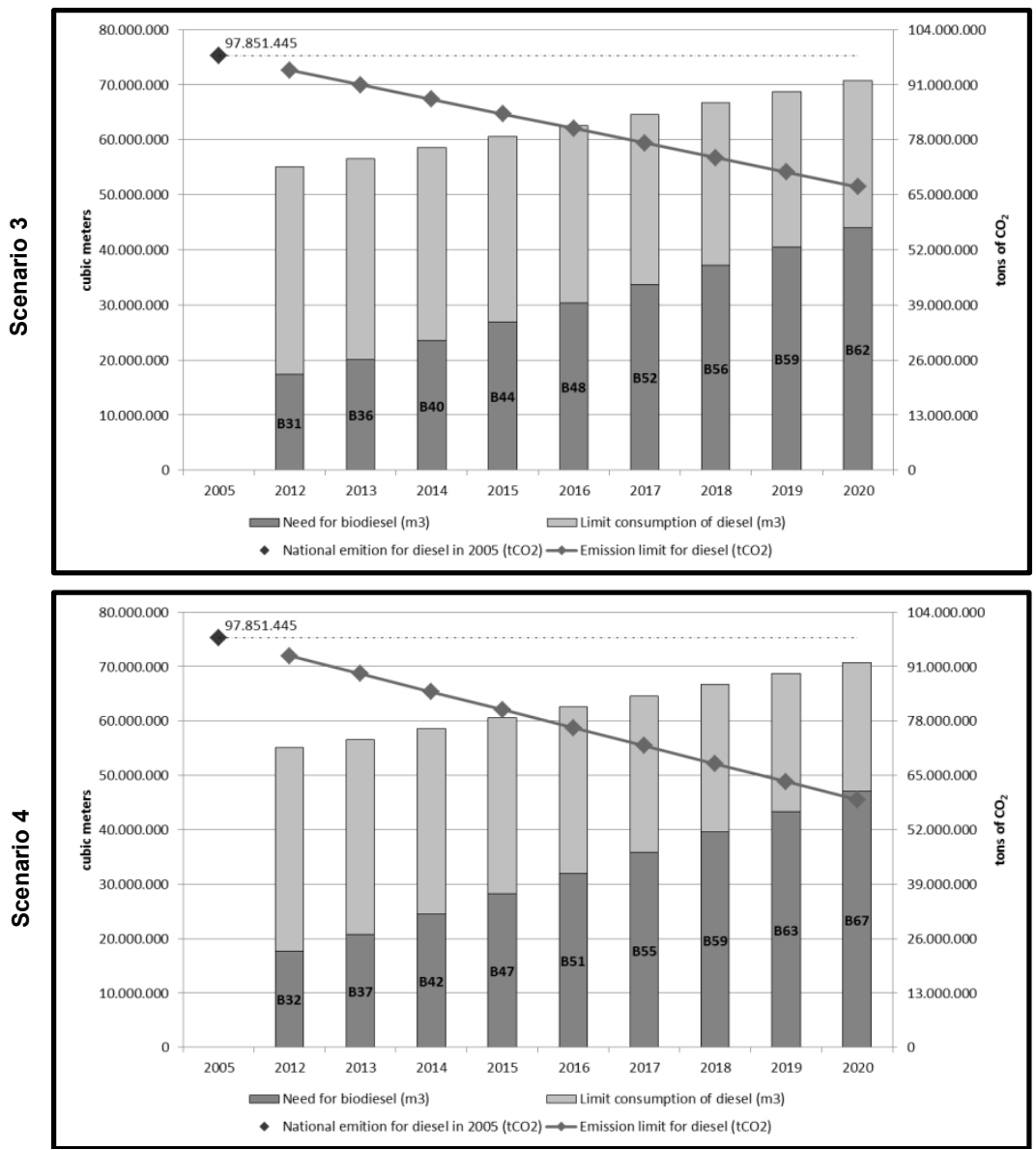

Source: Own elaboration.

From the forecasted scenarios it was observed that the need for biodiesel increase average is between $11.56 \%$ and $12.93 \%$ per year in the period, while the need to reduce diesel is between 2.94\% and 5.54\% per year from 2012 to 2020 (Table 8). This reveals a strong dependence of the economy on fossil energy derived from oil, knowing that to decrease approximately $4 \%$ of the need for diesel fuel is needed triple of biodiesel to supply the energy needs. Although the insertion of the use of renewable energies as an alternative substitute for exhaustible resources, the efficiency level of those are shown low.

Another questionable point is the goal of reducing emissions of carbon dioxide taken up by the Brazilian federal government in the NPCC. While the 
Kyoto Protocol for developed countries undertake to mitigate $5.2 \%$ of the collective emissions of greenhouse gases of 1990 in the period from 2008 to 2012 (ESTEBAN, FEIJOÓ and HERNANDEZ, 2003), Brazil has a too high commitment. It's assumed in the NPCC to reduce emissions of $\mathrm{CO}_{2}$ equivalent in 2005 from $36.1 \%$ to $38.9 \%$ by the year 2020 , setting physical goals for $\mathrm{CO}_{2}$ for those systems with high participation in the emission of gaseous effluents such as deforestation, livestock activity, soil change and energy.

Table 8

Geometric growth rate (GGR) predicted consumption of biodiesel and diesel, 2012-2020

\begin{tabular}{c|cc|cc}
\hline \multirow{2}{*}{ Scenarios } & \multicolumn{2}{|c|}{ Biodiesel } & \multicolumn{2}{c}{ Diesel } \\
\cline { 2 - 5 } & GGR & \multicolumn{1}{c}{ Tests } & GGR & \multicolumn{1}{c}{ Tests } \\
\hline Scenario 1 & 11,56 & $\begin{array}{l}\mathrm{R}^{2}=0,9888 \\
\text { Test } \mathrm{t}=24,8765^{*}\end{array}$ & $-2,94$ & $\begin{array}{l}\mathrm{R}^{2}=0,9989 \\
\text { Test } \mathrm{t}=-78,1390^{*}\end{array}$ \\
\hline Scenario 2 & 11,72 & $\begin{array}{l}\mathrm{R}^{2}=0,9884 \\
\text { Test } \mathrm{t}=24,4425^{*}\end{array}$ & $-3,20$ & $\begin{array}{l}\mathrm{R}^{2}=0,9986 \\
\text { Test } \mathrm{t}=-70,4685^{*}\end{array}$ \\
\hline Scenario 3 & 12,30 & $\begin{array}{l}\mathrm{R}^{2}=0,9868 \\
\text { Test } \mathrm{t}=22,9087^{*}\end{array}$ & $-4,20$ & $\begin{array}{l}\mathrm{R}^{2}=0,9976 \\
\text { Test } \mathrm{t}=-54,1967^{*}\end{array}$ \\
\hline Scenario 4 & 12,93 & $\begin{array}{l}\mathrm{R}^{2}=0,9850 \\
\text { Test } \mathrm{t}=21,4488^{*}\end{array}$ & $-5,54$ & $\begin{array}{l}\mathrm{R}^{2}=0,9958 \\
\text { Test } \mathrm{t}=-40,7568^{*}\end{array}$ \\
\hline
\end{tabular}

* Statistically significant at $1 \%$.

Source: Own elaboration.

Once estimated these possible amounts of biodiesel it becomes opportune to estimate the need for raw materials to meet the future growing demand. Especially when it has consolidated the monoculture of soybeans for biodiesel production, which contradicts one of the requirements (sustainability) in the National Program for Production and Use of Biodiesel (NPPB). A sustainable model isn't necessarily specialized in a single crop.

\section{CONSIDERATIONS}

The data show that consumption of diesel in Brazil for the coming years has increasing tendency considering limits in the use of this, based in the theoretical framework of ecological economics to set usage limits on exhaustible resources, however it requires a decrease in consumption. And to meet a growing demand for this type of fuel it opens the need for a substitute, in this case, renewable.

If the traditional diesel consumption delays as estimated, its emissions shall be increasing. The forecast showed that the emissions of Brazil for mineral diesel can evolve from 137.8 to 176.7 million tons of $\mathrm{CO}_{2}$ from 2012 to 2020 . 
From NPCC goals, it was possible to identify four possible limits on emissions in Brazil, here restricted to those resulting from the use of diesel, to be accomplished until 2020. The first goal is proportional to reduce diesel emissions by $23.3 \%$, requiring biodiesel blends between B31 and B58 from 2012 to 2020. The second goal seeks to mitigate $25.1 \%$, with the evolving of biodiesel blends from B31 to B59. The third goal aims to reduce 30.937 million $\mathrm{tCO}_{2}$, for it is necessary from $\mathrm{B} 31$ to $\mathrm{B} 62$. The fourth goal aims to reduce 38.671 million $\mathrm{tCO}_{2}$, requiring higher levels of biodiesel, between B32 and B67. In 2013 the blend is still in B5.

The proposal to achieve these goals means a national reduction effort from each state to mitigate their level of emissions for 2005. It is known that Brazil is composed of twenty seven different economies (27 states with specific characteristics) with different energy matrices. Having in view the accomplishment of the NPCC measures, the NPPB needs to review the characteristics of these economies and the fulfillment and establishment of biodiesel with diesel oil blends.

Another consideration from the constructed scenarios that forecast a bigger demand for biodiesel, is to reflect about the biomass that originates it. It is known that domestic biodiesel production has been directed by soybean oil (average share of $80.53 \%$ in 2011). And the Brazilian government forecast is that soybean continues to be the "fundament" of raw material for biodiesel production. From a purely economic point of view, the prediction of a high need for biodiesel is well regarded by biodiesel factory owners, as well as by soybean farmers when it comes to soybean biodiesel. However, this is a controversy even for the own NPPB whose policy says it is modeled on the basis of sustainability, which defines the necessity of having diversity of agricultural cultures and sub-products as raw materials. It is necessary to pay attention to avoid the presence of lock-in on systems that have an intensive use of land and capital and that are highly specialized in a single crop.

Many studies have been done to show the existence of other promising biomasses with high conversion in oil, such as jatropha, castor, sunflower and sesame. The main obstacle is finding a technological and institutional arrangement for the production of oilseeds to ensure substitutability of fuels without compromising food supply. Given the diversity of oilseeds species, it is important to investigate the sustainable mosaics of raw material for the conversion of biomass into green fuels production, ensured by both family and corporate agriculture. 


\section{REFERENCES}

ALVARES JR., O. M.; LINKE, R. R. A. (2001). Metodología Simplificada de Cálculo das Emissões de Gases do Efeito Estufa de Frotas de Veículos no Brasil. São Paulo, CETEBS.

BRASIL. AGÊNCIA NACIONAL DO PETRÓLEO, GÁS NATURAL E BIOCOMBUSTÍVEIS (ANP) (2012). Vendas, pelas distribuidoras, dos derivados combustíveis de petróleo por Unidade da Federação e produto - 2000-2010 $\left(\mathrm{m}^{3}\right)$.xls. Available on: http://www.anp.gov.br/?dw=11031. [Acessed on: nov. 2012.]

CASA CIVIL. LEI No 12.187, DE 29 DE DEZEMBRO DE 2009. Institui a Política Nacional sobre Mudança do Clima - PNMC e dá outras providências. DOU de 30.12.2009. Brasília, 2009.

CAVALVANTI, C. (2010). "Concepções da economia ecológica: suas relações com a economia dominante e a economia ambiental". Revista de Estudos Avançados n. 24. 2010.

CECHIN, A. A. (2010). Natureza como limite da economia - A contribuição de Nicholas Georgescu-Roegen. São Paulo: Senac São Paulo/ Edusp.

CECHIN, A.; VEIGA, J. E. (2010). "O fundamento central da economia ecológica”. Cap. 2. In: MAY, P. (org.). Economia do Meio Ambiente: Teoria e Prática. (pp. 45-94) 2. ed. Rio de Janeiro: Elsevier.

DALY, H. E. A (1991). Economia ecológica e o desenvolvimento sustentável. Texto para Debate n. 34. John Cunha Comerford (trad.). Rio de Janeiro/RJ.

DALY, H. E.; FARLEY, J. (2004). Economia Ecológica: Princípios e Aplicações. Coleção Economia e Política. Alexandra Nogueira, Gonçalo C. Feio, Humberto N. Oliveira (trad.). Lisboa/Portugal: Instituto Piaget.

ESTEBAN, L.; FEIJOÓ, M; HERNÁNDEZ, J.M. (2003). "Eficiencia energética y regulación de la industria española ante el cambio climático". Estudios de Economía Aplicada, 21(2), pág. 259-282.

FUNDAÇÃO GETÚLIO VARGAS. FGV PROJETOS (2010). O biodiesel e sua contribuição ao desenvolvimento brasileiro. União Brasileira do Biodiesel (UBRABIO). São Paulo: FGV/UBRABIO, out.

GUJARATI, D. N. (2006). Econometria Básica. (1 ed.) Rio de Janeiro: Elsevier.

MAY, P. H. (org.) (2010). Economia do Meio Ambiente - Teoria e Prática. Prefácio. (2 ed.) Rio de Janeiro: Elsevier.

MINISTÉRIO DA CIÊNCIA E TECNOLOGIA (MCT). Segunda Comunicação Nacional do Brasil à Convenção - Quadro das Nações Unidas sobre Mudança do Clima. V. 1 e 2. Brasília: 2010. Available on: http://www.mct.gov.br/index.php/content/ view/326751.html. [Acessed on: 26 jan. 2011].

MINISTÉRIO DE MINAS E ENERGIA (MME). Matriz Energética Nacional 2030. 2007. Available on: http://www.mme.gov.br/spe/galerias/arquivos/Publicacoes/ 
matriz_energetica_nacional_2030/MatrizEnergeticaNacional2030.pdf. [Acessed on: 28 fev. 2011].

MORETIN, P. A.; TOLOI, C. M. C. (2006). Análise de Séries Temporais. (2 ed.) São Paulo: Egard Blucher.

PELLEGRINI, F. R. (2000). Metodologia para Implementação de Sistemas de Previsão de Demanda. Dissertação. Universidade Federal do Rio Grande do Sul. Porto Alegre/RS.

ROMEIRO, A. R. (2003). "Introdução: Economia ou Economia Política da Sustentabilidade". In MAY, P. H.; LUSTOSA, M.C.; VINHA, V. (org.) Economia do Meio Ambiente: Teoria e Prática (pp.1-29). Rio de Janeiro: Campus.

ROVĖRE, E. L.; COSTA, R. C. (2004). "Contabilização do balanço de carbono: indicadores de emissões de gases de efeito estufa". In ROMEIRO, A. R. (Org.). Avaliação e Contabilização de Impactos Ambientais (pp.153-169). Campinas: Editora da Unicamp, 2004.

SANTANA, A. C. (2003). Métodos Quantitativas em Economia - Elementos e Aplicações. Belém/PA: UFRA.

SANTOS, T.; CORREIO, L. S. (2011). "Perspectivas para a Discussão Teórica acerca do Meio Ambiente a partir da Evolução do Pensamento Econômico". Revista Wolfius. 1(1), p. 20-37. Avaible on: http://www.revistawolfius.com.br/ index.php/Wolfius/article/view/3/25. [Acessed on: 24 mai. 2011]. 
